\title{
Clinocerinae (Diptera : Empididae) from Corsica with the description of six new species
}

\author{
M.H.E. Pusch ${ }^{1}$
}

Keywords : Empididae, Clinocerinae, new species, Corsica.

During the summers 1992 and 1993, 15 species of Clinocerinae (Empididae) were collected on Corsica. The illustrated descriptions of six new species are given: Roederiodes wagneri sp. n., Clinocera (Kowarzia) cataractae sp. n., Wiedemannia (Chamaedipsia) ariolae sp. n., Wiedemannia (Chamaedipsia) bravonae sp. n., Wiedemannia (Philolutra) kallistes sp. n. and Wiedemannia (Wiedemannia) martini sp. n.. Their systematic relations with other species are discussed. Informations is given about their geographic distribution and their habitats.

Les Clinocerinae (Diptera : Empididae) de Corse avec la descriptión de six espèces nouvelles

Mots clés : Empididae, Clinocerinae, nouvelles espèces, Corse.

Pendant les étés 1992 et 1993, 15 espèces de Clinocerinae (Empididae) ont été récoltées en'Eorse. Les six espèces nouvelles sont décrites : Roederiodes wagneri sp. n., Clinocera (Kowarzia) cataractae sp. n., Wiedemannia (Chamaedipsia) ariolae sp. n., Wiedemannia (Chamaedipsia) bravonae sp. n., Wiedemannia (Philolutra) kallistes sp. n. et Wiedemannia (Wiedemannia) marti$n i$ sp. n.. Les relations systématiques avec d'autres espèces sont discutées. Des informations sur la distribution géographique et les habitats sont données.

\section{Introduction}

The island of Corsica is one of the most important centres of endemism for freshwater invertebrates in Europe. In that respect it can be compared with the Iberian peninsula and the Caucasus mountains (Illies 1966, Giudicelli 1975). With regard to its areal dimension, the concentration of endemic species on Corsica is even the highest in Europe, most of them have been found in springbrooks and streams of higher regions (Giudicelli 1975). This is also the major habitat of the Empidid subfamily Clinocerinae. Adults of the Clinocerinae can frequently be found there sitting near the water surface on stones which are projecting out of the

1. Brandenburgische Technische Universität Cottbus, Lehrstuhl Gewässerschutz, Seestr. 45, D-15526 Bad Saarow, Germany. streams, or hanging obliquely over them, and in hygropetric zones.

The Clinocerinae of Corsica have been studied scarcely up to now. Since the collection tour of Becker et al. (1910,), only Vaillant (1964) has studied them in more detailed way. Both collection tours lead to the description of one new endemic species of this subfamily, respectively. This paper reports the results of a sampling tour to springs, streams and rivers in the northern part of the island in 1992, and to the southern part of the island in 1993, covering 43 localities in total.

\section{List of localities}

The specimens of the Clinocerinae have been collected at the following localities using an exhaustor (Fig. 1). For the description of the localities, the French system of geographic graduation that differs somewhat from the international system is used. Unless specified, all the material was collected by the author (leg. Pusch). 


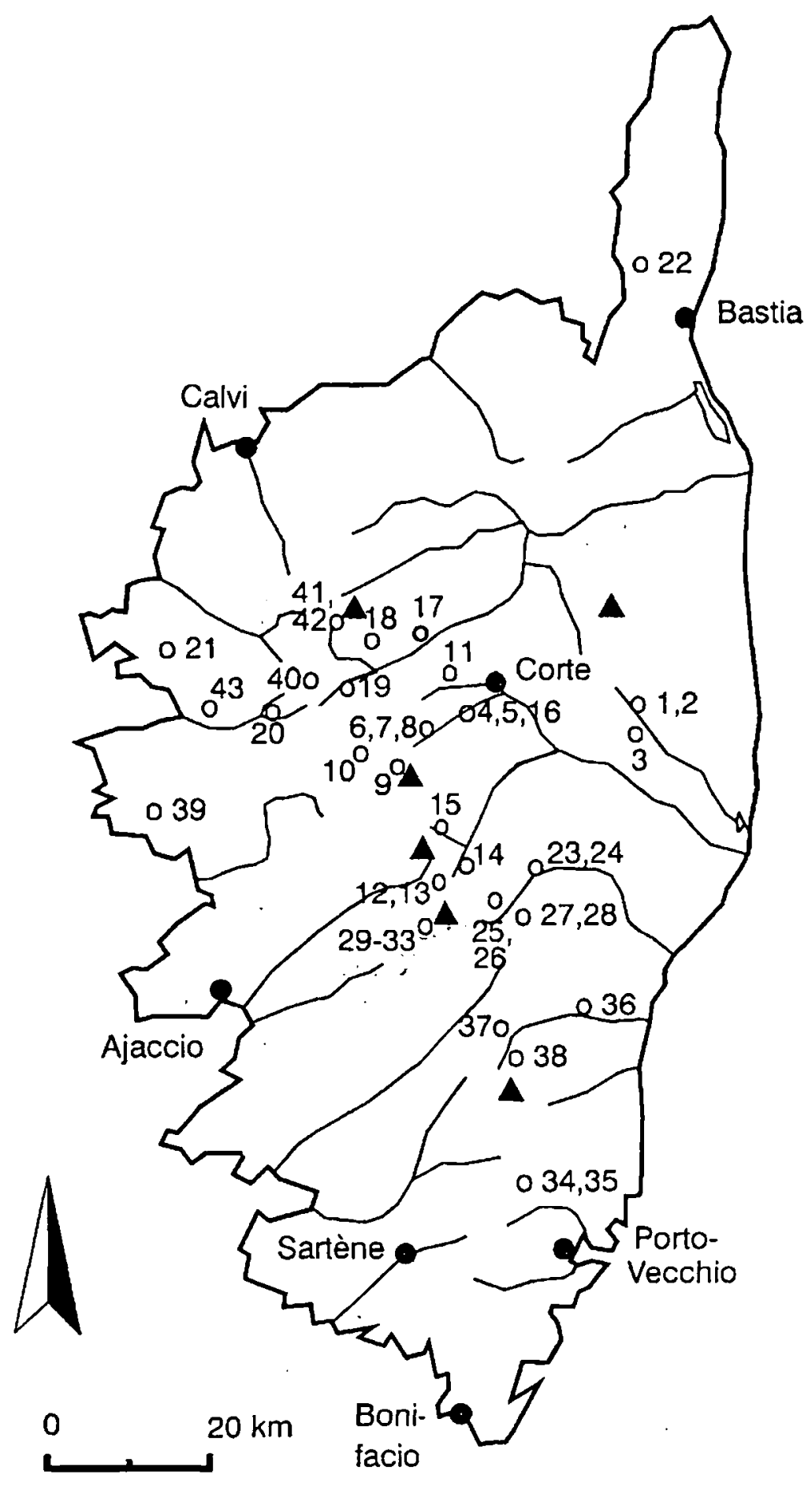

Fig. 1. Collection sites on the island of Corsica.

Fig. 1. Stations de récoltes sur l'île de Corse.

Station 1 : Rivière de Bravona, St. Vincent, Mazolla, $880 \mathrm{~m}$ a.s.l., $47^{\circ} 01^{\prime} \mathrm{N}, 7^{\circ} 47^{\prime}$. E; 3-4 $\mathrm{m}$ wide, in the shade, 23. 7. 1992.

Station 2 : Ruisseau de Sambuchetto, St. Vincent, Mazolla, $880 \mathrm{~m}$ a.s.l., $47^{\circ} 01^{\prime} \mathrm{N}, 7^{\circ} 47^{\prime} \mathrm{E}, 1 \mathrm{~m}$ wide, left tributary of Riv. de Bravona, sunny, 23. 7. 1992.

Station 3: Ruisseau de Canale, St. Vincent, Mazolla, $900 \mathrm{~m}$ a.s.l., $46^{\circ} 59^{\prime} \mathrm{N}, 7^{\circ} 47^{\prime} \mathrm{E}, 1 \mathrm{~m}$ wide, right tributary of Riv. de Bravona, hygropetric, in the shade, calcareous crust, 23. 7. 1992.

Station 4: Rivière Restonica near campground Tuani, Corte, near the road D623, $680 \mathrm{~m}$ a.s.l., $46^{\circ} 58^{\prime} \mathrm{N}, 7^{\circ} 32^{\prime} \mathrm{E}, 5-7 \mathrm{~m}$ wide, sunny, 25. 7.1992
Station 5: Ruisseau Bravino, near campground Tuani, Corte, D623, $680 \mathrm{~m}$ a.s.l., $46^{\circ} 58^{\prime} \mathrm{N}, 7^{\circ} 31^{\prime} \mathrm{E}, 2 \mathrm{~m}$ wide, in the shade, 25. 7. 1992.

Station 6: Rivière Restonica above Bergeria Grotelle, Corte, 1400 m a.s.l., $46^{\circ} 55^{\prime} \mathrm{N}, 7^{\circ} 26^{\prime} \mathrm{E}, 4 \mathrm{~m}$ wide, sunny, 26. 7. 1992.

Station 7: First left tributary of Riv. Restonica above Bergeria Grotelle, Corte, $1420 \mathrm{~m}$ a.s.l., $46^{\circ} 55^{\prime} \mathrm{N}, 7^{\circ} 26^{\prime} \mathrm{E}, 0.5-1 \mathrm{~m}$ wide, hygropetric, sunny, 26. 7. 1992.

Station 8: Second left tributary of Riv. Restonica above Bergeria Grotelle, Corte, $1425 \mathrm{~m}$ a.s.l., $46^{\circ} 55^{\prime} \mathrm{N}, 7^{\circ} 26^{\prime} \mathrm{E}, 1 \mathrm{~m}$ wide, hygropetric with moss, sunny, 26. 7. 1992.

Station 9: Springbrook above Lac de Melo near Bocca à Soglia, Corte, $1425 \mathrm{~m}$ a.s.l., $46^{\circ} 55^{\prime} \mathrm{N}, 7^{\circ} 26^{\prime} \mathrm{E}, 0.5 \mathrm{~m}$ wide, hygropetric with moss, sunny, 26. 7. 1992.

Station 10: Springbrook $50 \mathrm{~m}$ above Lac de Capitellu. Corte, 1935 $\mathrm{m}$ a.s.l., $46^{\circ} 54^{\prime} \mathrm{N}, 7^{\circ} 25^{\prime} \mathrm{E}, 0.5 \mathrm{~m}$ wide, hygropetric, 26. 7. 1992.

Station 11: Fiume Tavignano, $500 \mathrm{~m}$ below suspension bridge, Corte, $760 \mathrm{~m}$ a.s.l., $46^{\circ} 59^{\prime} \mathrm{N}, 7^{\circ} 31^{\prime} \mathrm{E}, 5-8 \mathrm{~m}$ wide, Clinocerinae in the shade, 27. 7. 1992.

Station: 12: Right tributary of Rau l'Agnone near Cascades des Anglais, Vizzavona, N193, $920 \mathrm{~m}$ a.s.l., $46^{\circ} 47^{\prime} \mathrm{N}, 7^{\circ} 32^{\prime} \mathrm{E}, 1-2 \mathrm{~m}$ wide, in the shade, partly hygropetric, 28. 7. 1992.

Station 13: Ruisseau l'Agnone near Cascades des Anglais, Vizzavona, $\mathrm{N} 193,1120 \mathrm{~m}$ a.s.l., $46^{\circ} 47^{\prime} \mathrm{N}, 7^{\circ} 31^{\prime} \mathrm{E}, 4 \mathrm{~m}$ wide, sunny, 28 7. 1992.

Station 14: Ruisseau d'Omenio above Tattone at the railway station, $\mathrm{N} 193,840 \mathrm{~m}$ a.s.l., $46^{\circ} 50^{\prime} \mathrm{N}, 7^{\circ} 34^{\prime} \mathrm{E}, 2 \mathrm{~m}$ wide, in the shade, 28. 7. 1992.

Station 15: Ruisseau de Manganello, $1 \mathrm{~km}$ above Canaglia, $720 \mathrm{~m}$ a.s.l., $46^{\circ} 51^{\prime} \mathrm{N}, 7^{\circ} 33^{\prime} \mathrm{E}, 8-10 \mathrm{~m}$ wide, sunny, 28. 7. 1992.

Station 16: Ruisseau de Figarello above campground Tuani, Corte, D623, $680 \mathrm{~m}$ a.s.1., $46^{\circ} 58^{\prime} \mathrm{N}, 7^{\circ} 33^{\prime} \mathrm{E}, 1 \mathrm{~m}$ wide, hygropetric, in the shade, 29. 7. 1992.

Station 17: Ruisseau de Ruda at Scala di Santa Regina, Calacuccia, D84, 540 m a.s.1., $47^{\circ} 04^{\prime} \mathrm{N}, 7^{\circ} 35^{\prime} \mathrm{E}, 1-2 \mathrm{~m}$ wide, sunny, 29. 7. 1992.

Station 18: Fiume Golo at the road to Col de Verghio, P. San Rimeriu, Albertacce, D84, $1137 \mathrm{~m}$ a.s.l., $46^{\circ} 58^{\prime} \mathrm{N}, 7^{\circ} 17^{\prime} \mathrm{E}, 4-6 \mathrm{~m}$ wide, sunny, Clinocerinae on big rocks, 29. 7. 1992.

Station 19: Little stream at D84 below and east of Col de Verghio, P. du Renaghiu, Albertacce, $1163 \mathrm{~m}$ a.s.1., $46^{\circ} 59^{\prime} \mathrm{N}, 7^{\circ} 17^{\prime} \mathrm{E}, 0.5 \mathrm{~m}$ "wide, hygropetric, 29. 7. 1992

Station 20: Little stream below Village de vacances d'Aitone below and west of Col de Verghio, Albertacce, D84, $1092 \mathrm{~m}$ a.s.l., $46^{\circ}$ $58^{\prime} \mathrm{N}, 7^{\circ} 14^{\prime} \mathrm{E}, 1 \mathrm{~m}$ wide, partly hygropetric, 29. 7. 1992.

Station 21: Spring (cased) near the road from Osani ( $4 \mathrm{~km}$ below) to Valeria, D81, $260 \mathrm{~m}$ a.s.l., $47^{\circ} 02^{\prime} \mathrm{N}, 7^{\circ} 01^{\prime} \mathrm{E}, 30.7 .1992$.

Station 22: Rivière Dolmeta near Negru, south of Nonza, Cap Corse, $80 \mathrm{~m}$ a.s.l., $47^{\circ} 31^{\prime} \mathrm{N}, 7^{\circ} 47^{\prime} \mathrm{E}, 2-3 \mathrm{~m}$ wide, 3. 8. 1992.

Station 23: Ruisseau de Chigeri above Ghisoni at the ascent to Bergeria de Rimugeto, D69, $720 \mathrm{~m}$ a.s.l., $46^{\circ} 45^{\prime} \mathrm{N}, 7^{\circ} 37^{\prime} \mathrm{E}, 4 \mathrm{~m}$ wide, $\mathrm{pH} 7.3,64 \mu \mathrm{S}, 18^{\circ} \mathrm{C}$ (at $12 \mathrm{a} . \mathrm{m}$.) slightly shady, on a overhanging stone many specimen, 7. 8. 1993.

Station 24: Hygropetric wall of rock above Ghisoni, at the ascent to Bergeria de Rimugeto, $200 \mathrm{~m}$ above $\mathrm{D} 69,740 \mathrm{~m}$ a.s.l., $46^{\circ} 45^{\prime} \mathrm{N}$, $7^{\circ} 37^{\prime} \mathrm{E}, 1 \mathrm{~m}$ wide, sunny, 7. 8. 1993.

Station 25: Ruisseau de Lischetto south of Ghisoni, left tributary of Fiume Orbu, $1 \mathrm{~km}$ above D69, $1040 \mathrm{~m}$ a.s.l., $46^{\circ} 72^{\prime} \mathrm{N}, 7^{\circ} 59^{\prime} \mathrm{E}$, 1-2 $\mathrm{m}$ wide, $16^{\circ} \mathrm{C}$ (at 4 p. m.), pH 7.9, $63 \mu \mathrm{S}, 7.8 .1993$. 
Station 26: Ruisseau de Cannarecchia south of Ghisoni, $1 \mathrm{~km}$ above D69, $1040 \mathrm{~m}$ a.s.l., $46^{\circ} 73^{\prime} \mathrm{N}, 7^{\circ} 59^{\prime} \mathrm{E}, 6 \mathrm{~m}$ wide, high gradient, in the shade, 7. 8. 1993.

Station 27: Right tributary of Fiume Orbu south of Ghisoni near Maison Forêt. de Marmano, D69, $950 \mathrm{~m}$ a.s.1., 46 $71^{\circ} \mathrm{N}, 7^{\circ} 62^{\prime} \mathrm{E}$, $2 \mathrm{~m}$ wide, 7. 8. 1993

Station 28: Ruisseau d'Ariola, right tributary of Fiume Orbu south of Ghisoni, D69, $960 \mathrm{~m}$ a.s.l., $46^{\circ} 7 \mathrm{I}^{\prime} \mathrm{N}, 7^{\circ} 63^{\prime} \mathrm{E}, 4 \mathrm{~m}$ wide, $\mathrm{pH}$ $7.8,16^{\circ} \mathrm{C}$ (at 8 p. m.) $50 \mu \mathrm{S}$, in the shade, low gradient, 7. 8. 1993.

Station 29: Ruisseau de Casso below Monte Renoso, south of Ghisoni, $1880 \mathrm{~m}$ a.s.l., $46^{\circ} 74^{\prime} \mathrm{N}, 7^{\circ} 56^{\prime} \mathrm{E}, 1 \mathrm{~m}$ wide, hygropetric, very high gradient, Clinocerinae only at one place at a sunny, hygropetric, big vertical wall of rock, 9. 8. 1993.

Station 30: Ruisseau de Tomba above Bergeria de Campanelle below Monte Renoso, south of Ghisoni, $1600 \mathrm{~m}$ a.s.l., $46^{\circ} 75^{\prime} \mathrm{N}, 7^{\circ}$ $57^{\prime} \mathrm{E}, 4 \mathrm{~m}$ wide, very high gradient, Clinocerinae at a vertical hygropetric wall of rock, 9. 8. 1993.

Station 31: Ruisseau de Tomba below Monte Renoso, south of Ghisoni, $1400 \mathrm{~m}$ a.s.l., $46^{\circ} 75^{\prime} \mathrm{N}, 7^{\circ} 58^{\prime} \mathrm{E}, 6 \mathrm{~m}$ wide, in the shade of the forest, 9. 8. 1993 .

Station 32: Ruisseau de Casso at the road to Monte Renoso, south of Ghisoni, $1350 \mathrm{~m}$ a.s. $1 ., 46^{\circ} 75^{\prime} \mathrm{N}, 7^{\circ} 59^{\prime} \mathrm{E}, 4 \mathrm{~m}$ wide, little right hygropetric tributary also investigated, 9. 8. 1993.

Station 33: Right tributary of Ruisseau de Casso at the road to Monte Renoso, south of Ghisoni, $840 \mathrm{~m}$ a.s.l., $46^{\circ} 74^{\prime} \mathrm{N}, 7^{\circ} 60^{\prime} \mathrm{E}, 2$ $m$ wide, in the shade of the forest, 9. 8. 1993.

Station 34: Ruisseau Piscia di Gallo north of Ospedale, D368, 800 $\mathrm{m}$ a.s.l., $46^{\circ} 31^{\prime} \mathrm{N}, 7^{\circ} 64^{\prime} \mathrm{E}, 8 \mathrm{~m}$ wide, hygropetric, below waterfall, 12. 8. 1993.

Station 35: Ruisseau Piscia di Gallo north of Ospedale, D368, 900 $\mathrm{m}$ a.s.l., 46 $31^{\prime} \mathrm{N}, 7^{\circ}$ 64' E, $4 \mathrm{~m}$ wide, sunny, 12. 8. 1993.

Station 36: Spring at the D 268 above Ruisseau de Fiumicelli, NE of Col de Bavella, $300 \mathrm{~m}$ a.s.l., $46^{\circ} 48^{\prime} \mathrm{N}, 7^{\circ} 74^{\prime} \mathrm{E}$, sunny, 14. 8 . 1993.

Station 37: Ruisseau di Polischellu at the D 268, NE of Col de Bavella, $450 \mathrm{~m}$ a.s.l., $46^{\circ} 47^{\prime} \mathrm{N}, 7^{\circ} 69^{\prime} \mathrm{E}, 6 \mathrm{~m}$ wide, in the shade, big rocks, 14. 8. 1993.

Station 38: Fontana di Cannone at the D 268, NE of Col de Bavella, Village de Bavella, $1050 \mathrm{~m}$ a.s.l., $46^{\circ} 44^{\prime} \mathrm{N}, 7^{\circ} 66^{\prime} \mathrm{E}, 1 \mathrm{~m}$ wide, hygropetric, in the shade, 14. 8. 1993.

Some additional specimens were kindly donated by Dr. R. Gerecke:

Station 39: Stream near Bocca di Gradella, Cargèse, Foret d'Esigna, $300 \mathrm{~m}$ a.s.l., 29. 5. 1993, leg. Gerecke \& Bückle.

Station 40: Springbrook, Capu a Rughia, Albertacce, $1350 \mathrm{~m}$ a.s.l., 5. 6. 1993, leg. Gerecke \& Bückle

Station 41: Golo-springbrook below Berg. de Tula, Albertacce, $1700 \mathrm{~m}$ a.s.1., 6. 6. 1993, leg. Gerecke \& Bückle.

Station 42: Fta. Monti Nielli, Bocca di Foggiale, $1800 \mathrm{~m}$ a.s.1., 6. 6. 1993, leg. Gerecke \& Bückle.

Station 43: Ruisseau d'Enova, Porto, $\mathrm{N}$ of Crète d'Andatone, 390 m a.s.l., 8. 6. 1993, leg. Gerecke \& Bückle.

\section{Collected species}

All specimens including the type material is preserved in $75 \%$ alcohol and deposited in coll. M. H. E. Pusch (Berlin).

\section{Dolichocephala ocellata - group}

Material: 6. 6. 1993, station 42, 1 \%.

On account of the wing venation and the color pattern of the wings, this female belongs to the Dolichocephala ocellata - group where some new species have been recently described (Wagner 1995). Besides this species, that has been collected near a spring in $1800 \mathrm{~m}$ a.s.l., Dolichocephala guttata (Haliday, 1833) is the only other Dolichocephala species known from Corsica (Becker et al. 1910).

\section{Roederiodes gereckei Wagner \& Horvat, 1993}

Material: 29. 7. 1992, station 20,1 0'; 3. 8. 1992 station 22, 1 \&; 8. 6. 1993, station 43, 1 o; 7. 8. 1993, station 23, 1 \%; 7. 8. 1993, station 25,7 ơ 4 \%; 7. 8. 1993, station 26,1 \%; 7. 8. 1993, station 28, 10 \% 3 ㅇ․

This species occurs on the neighbouring island of Sardinia, too (Wagner \& Horvat 1993). On Corsica R. gereckei has been found mainly in shady places at streams, both in hygropetric zones, and on stones projecting above the water surface. The streams were 1-6 $\mathrm{m}$ wide at altitudes between 390 and $1092 \mathrm{~m}$ a.s.l. The $\mathrm{pH}$ of the streamwater ranged from 7.3 to 7.9 , the electric conductivity from 50 to $63 \mu \mathrm{S} / \mathrm{cm}$.

\section{Roederiodes wagneri sp. $\mathrm{n}$.}

Material: Holotype ơ, France : Corsica, south of Ghisoni, Rau de Tomba above Bergeria de Campanelle, below Monte Renoso, at $1600 \mathrm{~m}$ a.s.l., $46^{\circ} 75^{\prime} \mathrm{N}$, $7^{\circ} 57^{\prime}$ E, 9. 8. 1993, paratypes $20^{\top} 2$ ㅇibidem; in coll. M. H. E. Pusch.

\section{Description}

Head dark brown with an elongate vertical proboscis about $2 / 5$ as long as head height. Eyes dark brown, ovoid. One pair of diverging ocellar, one pair of vertical and 3-7 (mean 5) postocular bristles in a single row, palpi dark brown bearing a few pale hairs.

Pronotum with one pair of black bristles, mesonotum dark brown with 2-3 pairs of acrostichals, 5 pairs of dorsocentrals, 1 humeral, 1 presutural, 1 notopleural and some other short thin bristles near them, 1 postalar bristle. Scutellum with two long and two short apical and some weak preapical scutellar bristles.

Legs brown, hind legs with the second tarsal segment twice as long as the fourth. Wings brownish translucent without stigma. Basicostal bristle present. Anterior wing margin with two differing kinds of setae.

Abdomen brown. Male genitalia (Fig. 2) with hypandrium about as long as or slightly shorter than gonocoxit. Gonocoxit triangular, rounded at upper margin. Gonostylus longer than wide, simple, triangular shaped, with a straight (rectilinear) caudal side (Figs. 

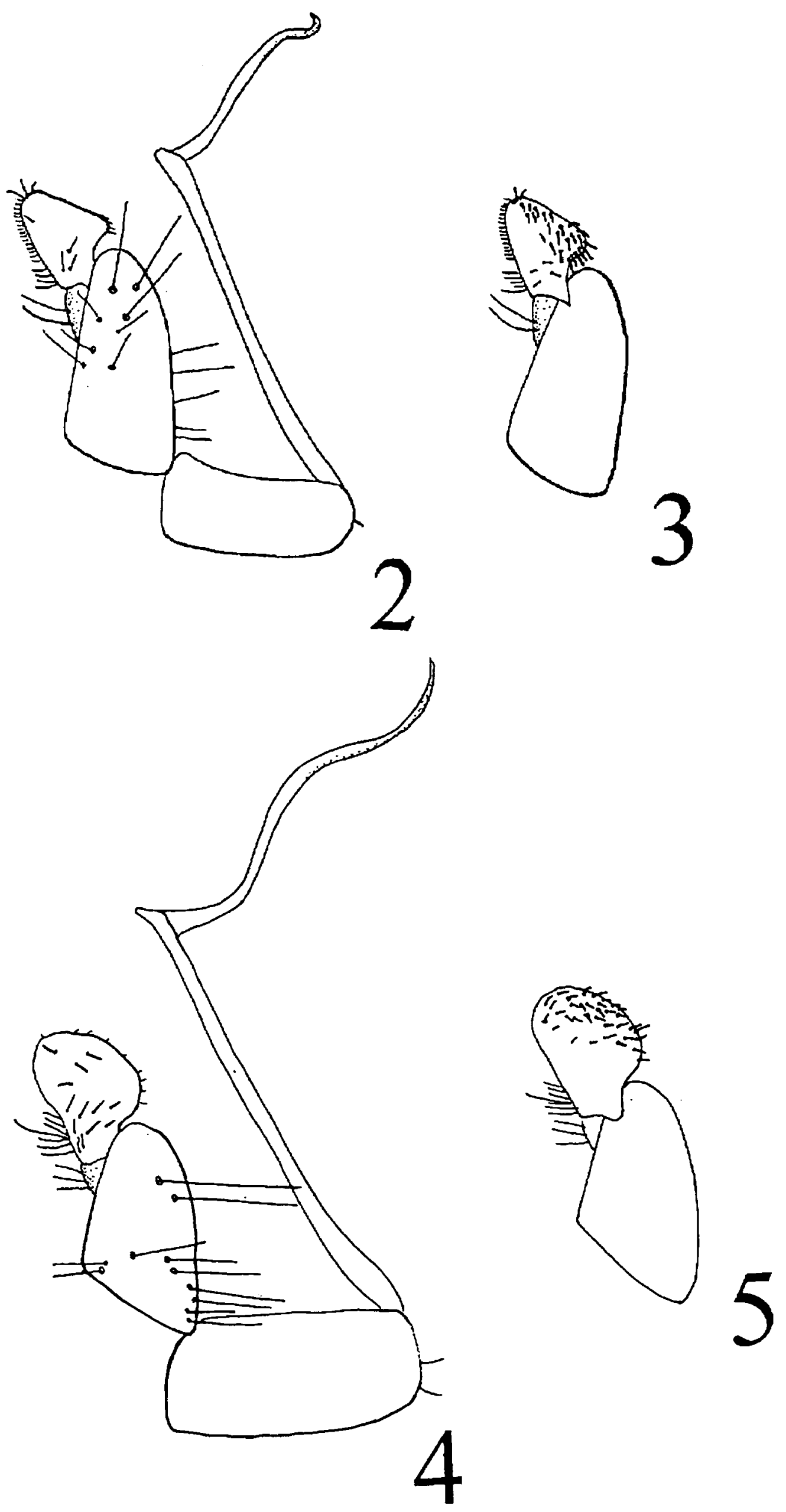

Figs 2-5. Lateral view of male genitalia. Outer view $(2,4)$ and inner view $(3,5)$. Figs 2, 3: Roederiodes wagneri sp. $n$. Figs 4 , 5 : Roederiodes oldenbergi (Engel).

Figs. 2-5. Vue latérale des genitalia $0^{*}$. Vue externe $(2,4)$ et interne $(3,5)$. Figs $2,3:$ Roederiodes.wagneri n.sp. Figs $4,5:$ Roederiodes oldenbergi (Engel). 
$2,3)$. Inner surface of the gonostylus is covered with setae mainly on the caudal side (Fig. 3). Aedeagus elongate, twice as long as the hypandrium, filament approximately half as long as the basal part.

Size: Wing length: $2.3-2.5 \mathrm{~mm}\left(\sigma^{7} \sigma^{7}\right), 2.5-2.8$ $\mathrm{mm}$ ( \& ). Body length: $2.2-2.4 \mathrm{~mm}\left(0^{7} \sigma^{7}\right), 2.5-2.8$ $\mathrm{mm}$ ( $\%$ ).

\section{Relations}

$R$. wagneri sp. $\mathrm{n}$. is a close relative to $R$. oldenbergi (Engel). Both species have a gonostylus longer than wide (Figs. 2, 4), and their second tarsal segment is twice as long as the fourth. The new species can easily be distinguished from $R$. oldenberg $i$ by the different shape and chaetotaxy of the gonostylus, and the different length of the aedeagal filament. The gonostylus of $R$. wagneri is triangularly shaped, its caudal margin is straight and its anterior margin has a row of fine setulae. The gonostylus of $R$. oldenbergi is ovoid (Figs. 4, 5 ), its caudal margin is convex and rounded, its anterior margin without a row of fine setulae. The aedeagal filament of $R$. wagneri is approximately half as long, and that of $R$. oldenbergi $2 / 3$ as long as the basal part.

Thus, the key from Wagner \& Horvat (1993) to male adults of the European species of Roederiodes can be supplemented as follows:

3 Gonostylus simple, ovoid or triangular 4

4 Proboscis 2/5 as long as head height; hind legs with second tarsal segment twice as long as the fourth; gonostylus longer than wide

Proboscis $1 / 3$ as long as the head height; hind legs with second tarsal segment slightly longer than the fourth, gonostylus wider than long

4a Aedeagal filament approximately $2 / 3$ as long as the basal part,-gonostylus ovoid, with caudal margin convex and rounded R. oldenbergi

Aedeagal filament approximately $1 / 2$ as long as the basal part, gonostylus triangular, with caudal margin straight

R. wagnerisp. $\mathrm{n}$.

Etymology

The new species is dedicated to Prof. Dr. R. Wagner at the Limnologische Flußstation des Max-Planck-Instituts für: Limnologie at Schlitz, Germany.

Up to now Roederiodes wagneri has been found only at one place in Corsica in the Rau. de Tomba at 1600 $\mathrm{m}$ a.s.l., which is $4 \mathrm{~m}$ wide, with a very steep gradient. $R$. wagneri was sitting on a big vertical hygropetric rock. There it occurred together with 8 other species: Clinocera (Clinocera) appendiculata (Zetterstedt), $C$. (Clinocera) nigra Meigen, C. (Kowarzia) bipunctata (Haliday), C. (Kowarzia) schnabli (Becker), C. (Kowarzia) tibiella Mik, Wiedemannia (Chamaedipsia) corsicana Vaillant, W. (Roederella) czernyi (Bezzi) und W. (Wiedemannia) martini sp. n.. Hence the Rau de Tomba proved to be surprisingly rich of Clinocerinae species. Two additional species could be found at the same stream at $1400 \mathrm{~m}$ a.s.l.: W. (Chamaedipsia) cataractae sp. n. and W. (Philolutra) kallistes sp. n.. Thus in total 11 Clinocerinae species occurred within a stream section of $700 \mathrm{~m}$.

\section{Clinocera (Clinocera) appendiculata (Zetterstedt, (1838))}

Material: 26. 7. 1992, station 8, 1 ơ 2 \%; 26. 7. 1992 , station 9, 2 ơ 3 \%; 26. 7. 1992, station 10, 4 o' 4 \%; 9. 8. 1993, station 29, 22 o $^{7} 18$ \%; 9. 8. 1993, station 30, 1 o'.

This species that is largely distributed in whole Europe (Chvala \& Wagner 1989) has been found on Corsica for the first time. There it was found only at sunny hygropetric zones, usually near little springbrooks of 1 $\mathrm{m}$ width between 1425 and $1935 \mathrm{~m}$ a.s.l.

\section{Clinocera (Clinocera) nigra Meigen, 1804}

Material: 23. 7. 1992, station 3, 1 ơ 2 9; 26. 7. 1992, station 8, 10"; 29. 7. 1992, station 16, 7 o' 11 \%; 29.7 . 1992, station 18, $10^{7} ; 29.7$. 1992, station $20,20^{7} ; 7.8$. 1993, station 25, 1 \%; 7. 8. 1993, station 26, 1 o' 1.\%; 7 . 8. 1993, station 27, 1 \&; 7. 8. 1993, station 28, 3 \%; 9. 8. 1993, station 29, 6 o' 3 \%; 9. 8. 1993, station 30, 7 o' 6 \%; 9. 8. 1993, station 31,3 ơ 2 \%; 9. 8. 1993, station 32,1 o' 2 \%; 12. 8. 1993, station 34,1 \%; 14. 8. 1993, station 38,4 O’ 3 o .

C. (C.) nigra Meigen is distributed in the whole of Europe, and in North Africa (Chvala \& Wagner 1989). It has been frequently found on Corsica (Becker et al. 1910, Vaillant 1964). It occurs usually in hygropetric zones at streams $1 \mathrm{~m}-6 \mathrm{~m}$ wide from 80 to $1880 \mathrm{~m}$ a.s.l.

\section{Clinocera (Kowarzia) bipunctata (Haliday, 1833)}

Material: 9. 8. 1993, station 30, 1 ơ 1 \%; 12.8. 1993, station $34,10^{7} 9$ \&; 14. 8. 1993, station 36, 1 \%".

This species occurs in whole continental Europe and North Africa (Chvala \& Wagner 1989), and has been found on Sardinia and Creta, too (Wagner 1995). On Corsica, it has been collected between 300 and $1600 \mathrm{~m}$ a.s.l.

\section{Clinocera (Kowarzia) cataractae sp. $\mathbf{n}$.}

Material: Holotype ó, France : Corsica, Ruisseau de Canale, right tributary of Riv. de Bravona, near St Vincent, Mazolla, at $900 \mathrm{~m}$ a.s.l., $46^{\circ} 59^{\prime} \mathrm{N}, 7^{\circ} 47^{\prime} \mathrm{E}, 23$. 7. 1992, paratypes $140^{\prime \prime} 29$ \& ibidem; 28. 7. 1992, station 12, 1 o' 2 \%; 28. 7. 1992, station 14, 1 0' 4 \%; 29. 
5. 1993, station 39,3 o' 3 우 5. 6. 1993, station 40, 1 우; 7. 8. 1993, station 24,2 o' 1 \%; 7. 8. 1993, station 25,1 O'; 7. 8. 1993, station 26, 1 \%; 7. 8. 1993, station 28, 1 ơ 1 \&; 9. 8. 1993, station 31, 2 ơ 5 \&; 9. 8. 1993, station 33, 3 ơ 3 \%; 12. 8. 1993, station 34, 9 o' 10 \%; 14. 8. 1993, station 38, 10 O’ 7 \% in coll. M. H. E. Pusch.

\section{Description}

Head blackish brown. Eyes dark brown. A pair of diverging ocellar, a pair of vertical and 6-8 (mean 7.4) stoutish postocular bristles followed below by a few fine, yellowish bristles. Antennae and palpi dark brown.

Pronotum with one pair of pale fine bristles, mesonotum dark brown with 2-5 (mean 3.7) pairs of acrostichals, 5 pairs of dorsocentrals, 1 humeral, 1 presutural, 1-2 notopleural, 1 postalar bristle. Scutellum with two apical bristles.

Legs with front coxae and all femora yellow; second and third coxae and tarsi light brown. Femur one with a distal comb of setae. Tibia 3 dorsal with 3-5 (mean 4.2) stout black bristles on the distal third. All coxae with yellow hairs. Wings brownish with a faint elongate stigma.

Abdomen dark brown. Male genitalia (Figs 6, 7): Hypandrium small, with two long black bristles on the ventral side which are as long as the greatest width of the hypandrium. Gonocoxit of approximately triangular shape, with an elongate inner appendage which becomes narrower at its tip. Inner surface of the appendage with bristles longer than, or as long as the width of the appendage. Gonostylus long and slender, basal and distal part in about rectangular position to each other, distal part about 2 times longer than basal part. Inner surface of the gonostylus is covered with short dark setae (Fig. 7). Aedeagus strong, filament approximately half as long as the basal part.

Size: Wing length: 3.1-3.8 mm (mean 3.5) $\left(0^{7} \sigma^{7}\right)$, 3.3-3.8 mm (mean 3.7) (우). Body length: $2.8-3.8 \mathrm{~mm}$ (mean 3.2) (0' $0^{7}$ ), 2.8-3.8 mm (mean 3.2) (\$Q).

\section{Relations}

C. (Kowarzia) cataractae sp. $\mathrm{n}$. is a close relative to $C$. $(K$.) rivalis Wagner from Italy, $C$. $(K$.) sandaliae Wagner from Sardinia, $C$. (K.) jalonae Wagner from Spain and $C$. (K.) subplectrum Vaillant \& Vinçon from the French Pyrenees. A common feature of all five species is their approximately scythe - shaped gonostylus, and a longish inner gonocoxit appendage which becomes narrower towards its tip. The five species can be divided into two groups. The two western Mediterranean species $C$. (K.) jalonae and $C$. (K.) subplectrum have a gonostylus with its distal part 1.5 times longer than its basal part. In contrast in the central Mediterra- nean species $C$. (K.) rivalis, $C$. (K.) sandaliae and $C$. $(K$.) cataractae the distal part of the gonostylus is 2 times longer than its basal part. The new species can be distinguished from the mentioned four species first by the different coloration of the legs. Front coxae and all femora of the new species are yellow, whereas the legs of $C$. (K.) sandaliae and $C$. (K.) jalonae are uniformely brownish, in $C$. $(K$.) rivalis only the front coxae are yellow and in $C$. $(K$.) subplectrum the entire legs are yellow. The second difference is the ciliation of the gonostylus $-C$. $(K$.) cataractae has only three setae on the outer surface of the distal part of the gonostylus, whereas the other four species have more setae there. Further, $C$. $(K$.) cataractae sp. n. can be distinguished from ist closest relative $C$. $(K$.) sandaliae by the dorsal ciliation of third tibia. $C$. $(K$.$) sandaliae has 6-8 (mean$ $6.8)$ thorn shaped bristles distributed over the entire length of the tibia. The 3-5 (mean 4.2) thorn shaped bristles in $C .(K$.$) cataractae are only on the distal$ third.

\section{Etymology}

The new species has been found mainly in hygropetric zones e. g. near waterfalls, that is why the species name cataractae, the greek-latin name for waterfall, has been choosen.

C. (Kowarzia) cataractae has been found in many places on Corsica. It occurred in 1-6 m wide, sunny and shady streams between 300 and $1400 \mathrm{~m}$ a.s.l., both in hygropetric zones, and on stones projecting out of the water surface. At the twelve localities where the new species has been found, it cooccurred with $W .(R$. czernyi (Bezzi) seven times, with $W(C$.) corsicana Vaillant and with $C$. $(C$.) nigra Meigen five times. Other species that have been found in the same localities are $R$. gereckei Wagner \& Horvat, $C$. $(K$.$) schnabli$ (Becker), C. (K.) tibiella Mik, W. (Ch.) ariolae sp. n., $W$. (Ch.) bravonae sp. n., W. (P.) kallistes sp. n. and $W$. (W.) martini sp. n..

\section{Clinocera (Kowarzia) schnabli (Becker, 1910)}

Material: 26. 7. 1992, station 8, 3 ơ 1 \$; 26. 7. 1992, station 9, 2 O' 2 \%; 26. 7. 1992, station 10, 1 \%; 28. 7. 1992, station 12, 1 ơ 3 \%; 28. 7. 1992, station 14, 1 \%; 29. 7. 1992, station 19, 2 0'3 \%; 9. 8. 1993, station 30, 1 \%; 9. 8. 1993, station 32, $10^{\circ} 2$ \%; 9. 8. 1993, station 29,1 \%.

C. (Kowarzia) schnabli (Becker) is endemic on Corsica (Vaillant 1978). It has been found at sunny and shady hygropetric zones, mostly near little streams $0.5-1 \mathrm{~m}$ wide between 840 and $1935 \mathrm{~m}$ a.s.l. Additionally, Vaillant (1964) found this species on rocks of the sea shore. 


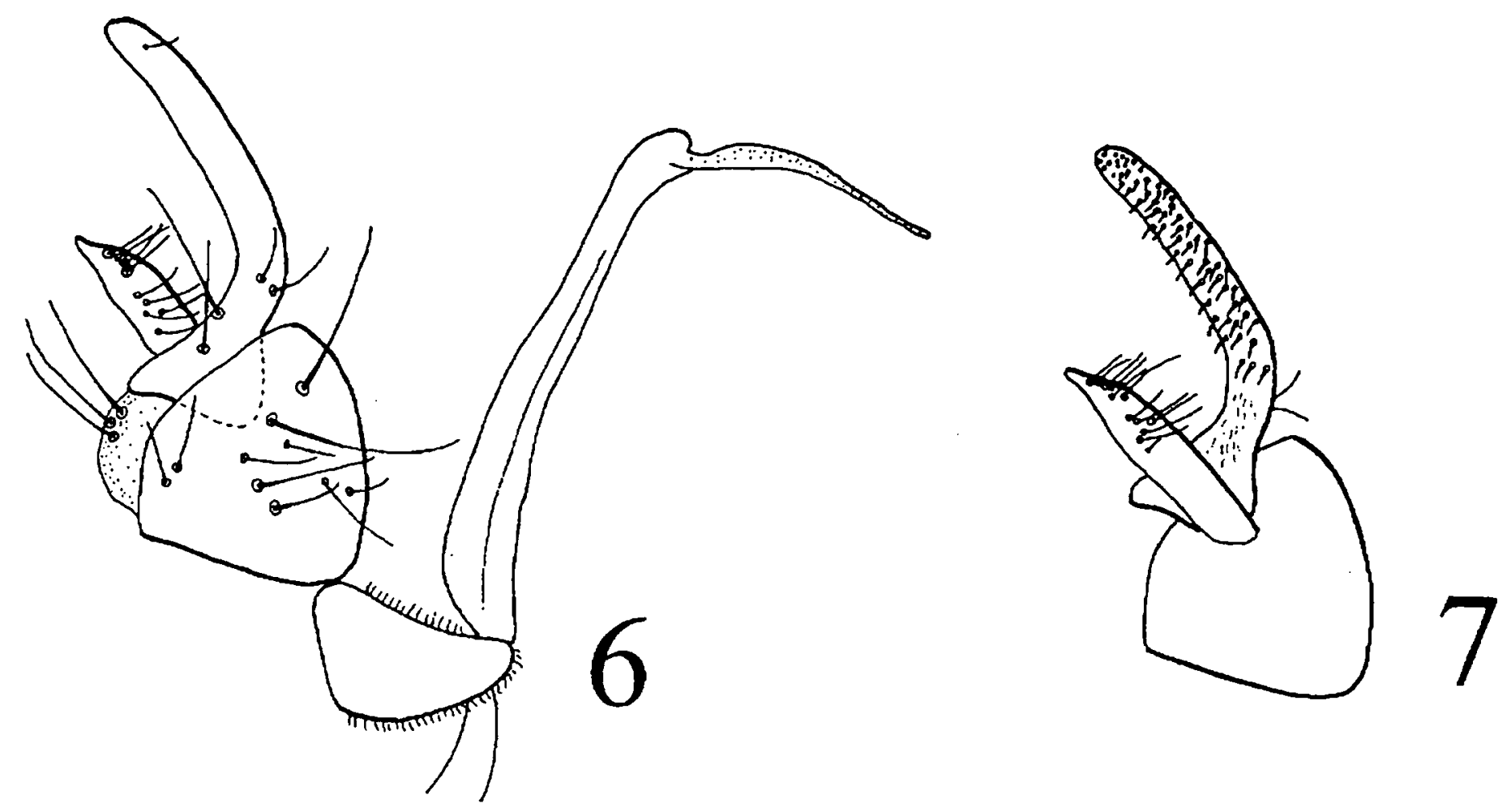

Figs 6-7. Lateral view of male genitalia of Clinocera (Kowarzia) cataractae sp. n. 6 outer view, 7 inner view. Figs 6-7. Vue latérale des genitalia ơ de Clinocera (Kowarzia) cataractae n.sp. vue externe (6), vue interne (7).

\section{Clinocera (Kowarzia) tibiella Mik, 1880}

Material: 26. 7. 1992 station 7, 3 ơ 4 \&; 26. 7. 1992 , station 8, 7 o' 17 \&; 26. 7. 1992, station 10, 1 \%; 29.7. 1992, station 16, 4 O $^{\prime \prime} 1$ ㅇ; 29. 7. 1992 station 18, 2 o $^{\circ} 1$ \&; 29. 7. 1992 station $19,10^{7} ; 30$. 7. 1992, station 21 , 1 ơ; 5. 6. 1993, station 40, 1 \%; 7. 8. 1993, station 24, $20 ; 9$. 8. 1993, station 29,20 \% ; 9. 8. 1993, station 30 , 2 o' 5 9; 9. 8. 1993, station 31, 1 0'; 9. 8. 1993, station 32, 27 o' 16 \&; 14. 8. 1993, station 38, 30'1 1 .

C. (Kowarzia) tibiella Mik is distributed over Germany, Austria, Italy and France (Chvala \& Wagner 1989). Its occurence on Corsica has already been reported by Vaillant (1964). It appeared from $3 \mathrm{~m}$ a.s.l. (Vaillant 1964) to $1935 \mathrm{~m}$ a.s.l., mostly on sunny hygropetric zones near little streams $0.5-1 \mathrm{~m}$ wide. However, it has been found at a $6 \mathrm{~m}$ wide stream, too.

\section{Wiedemannia (Chamaedipsia) ariolae sp. $\mathbf{n}$.}

Material: Holotype o', France : Corsica, Ruisseau de Polischellu, NE Col de Bavella, D 268, at $450 \mathrm{~m}$ a.s.l., $46^{\circ} 47^{\prime} \mathrm{N}, 7^{\circ} 69^{\prime} \mathrm{E}, 14.8$. 1993, paratypes 7. 8. 1993, station 28, $20^{\prime} 2$ in coll. M. H. E. Pusch.

\section{Description}

Head rounded, blackish brown with a pair of diverging ocellar, a pair of vertical and 4-6 (mean 4.7) biserial postocular bristles followed below by finer and pa- ler hairs that reach to the lower part of the occiput. Palpi bearing a few pale hairs.

Thorax brown, pronotum with one pair of bristles, mesonotum with 7-9 pairs of acrostichals, irregularly biserial, 5 pairs of dorsocentrals alternated by very fine and short bristles, 1 humeral, two fine posthumeral, 1 presutural and two short fine bristles near them, 2 notopleural and some other short bristles near them, 1 postalar, scutellum with two long and two short terminal bristles.

Legs brown, front femora with two distinct strong black bristles in the apical third. The distance between the two bristles is approximately equal to the double length of a bristle (Fig. 8). Front coxae with long pale hairs and two light brown bristles distinctly longer than width of coxa. Wings brownish translucent without stigma.

Abdomen brown. Male genitalia (Figs 9, 10): Hypandrium and aedeagus without specific features. Gonocoxit quadrate with rounded edges. Gonostylus approximately rhombic, its outer surface with some finer bristles and two distinct strong black bristles on its tip. Its inner surface is covered with many short black spines, mainly on the caudal side.

Size: Wing length: $3.8-4 \mathrm{~mm}\left(0^{7} \sigma^{7}\right), 4 \mathrm{~mm}$ (\$Q). Body length: $3.8 \mathrm{~mm}\left(\sigma^{\top} \sigma^{\top}\right), 3.8-4.2 \mathrm{~mm}$ (\%). 

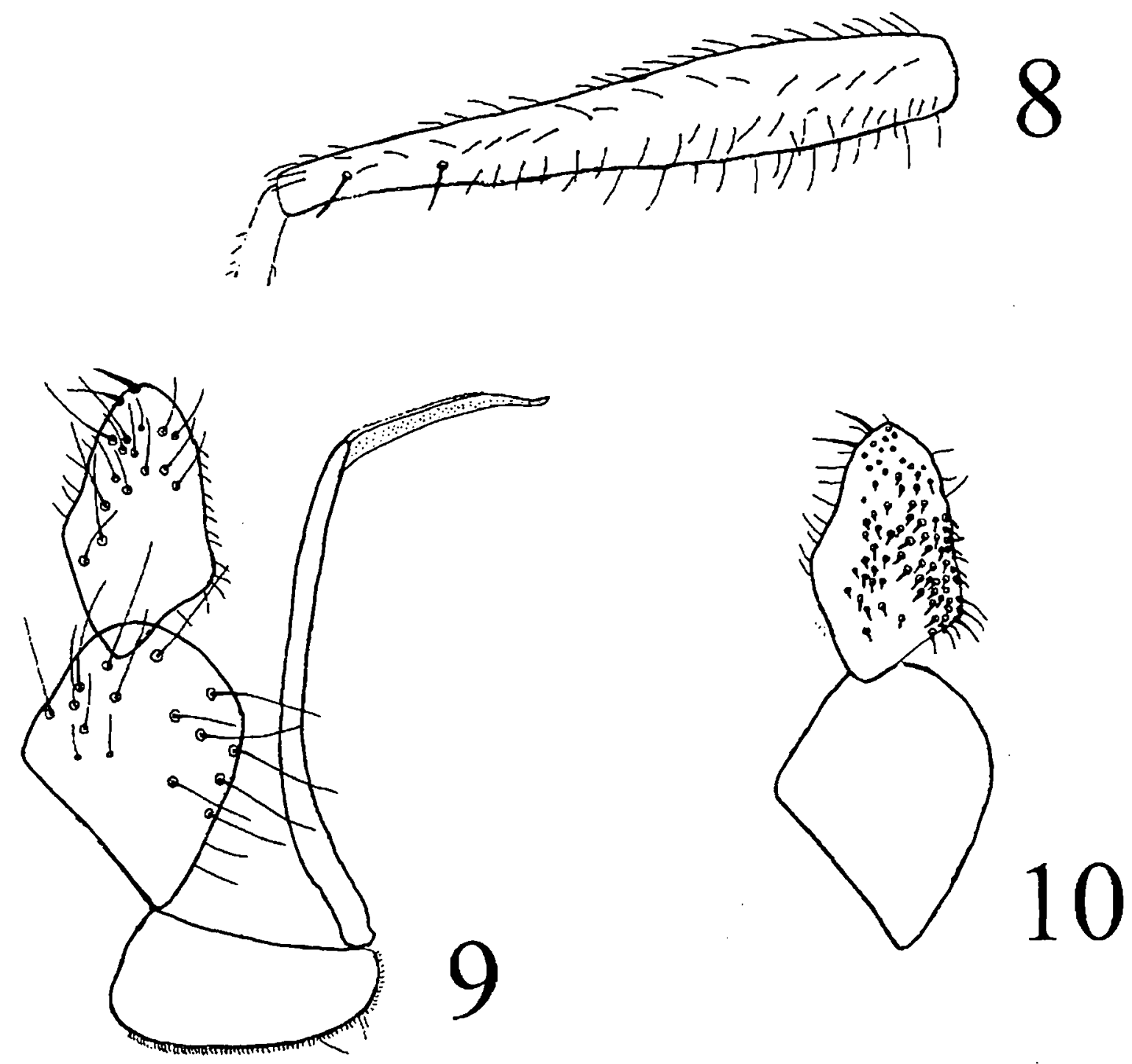

Figs 8-10. Wiedemannia (Chamaedipsia) ariolae sp. n.. Fig. 8: inner view of right front leg, femur and proximal part of tibia. 9, 10: lateral view of male genitalia. 9 outer view, 10 inner view.

Figs 8-10. Wiedemannia (Chamaedipsia) ariolae n.sp. $8:$ vue interne de la patte antérieure droite, fémur et partie proximale du tibia. 9 , $10:$ vue latérale des genitalia $\sigma^{7}$ : vue externe (9), vue interne (10).

\section{Relations}

The chaetotaxy and shape of the gonostylus distinguishes $W$. (Ch.) ariolae sp. $\mathrm{n}$. from its close relative $W$. (Ch.) beckeri Mik from the European continent: $W$. (Ch.) ariolae has two distinct strong bristles at the tip of the outer surface of the gonostylus which are absent in $W$. (Ch.) beckeri. A further difference is the absence of a stigma in W. (Ch.) ariolae, whereas $W(\mathrm{Ch}$.) beckeri has an elongate stigma.

\section{Etymology}

The species is named after the stream Rau d'Ariola where the species has been found.

W. (Chamaedipsia) ariolae has been found only at two shady streams (4-6 m wide) between 450 and 960 $\mathrm{m}$ a.s.l. The new species occurred together with $R$. gereckei Wagner \& Horvat, $C$. (C.) nigra Meigen, $C$. (K.) cataractae sp. n., W. (R.) czernyi (Bezzi),W. (Ch.) corsicana Vaillant, and W. (W.) martini sp. n.

\section{Wiedemannia (Chamaedipsia) bravonae sp. $\mathbf{n}$.}

Material: Holotype ơ, France : Corsica, Ruisseau de Canale, right tributary of Riv. de Bravona near St. Vincent, Mazolla, at $900 \mathrm{~m}$ a.s.l., $46^{\circ} 59^{\prime} \mathrm{N}, 7^{\circ} 47^{\prime} \mathrm{E}, 23.7$. 1992, paratypes $90^{\prime} 4$ ibidem in coll. M. H. E. Pusch.

\section{Description}

Head brown and rounded, with a pair of diverging ocellar and 3-5 (mean 4.4) black postocular bristles in a single row, followed below by paler bristles. Palpi brown, bearing a few pale hairs. 
Thorax brown, pronotum with one pair of pale bristles. Mesonotum with 4-8 (mean 5.6) pairs of acrostichals, 5-6 pairs of dorsocentrals, 1 humeral, $1-2$ presutural, and some short fine bristles near them, 2 notopleural, and some other short fine bristles near them, 1 postalar, scutellum with 2 long and 3-4 short terminal bristles, and some short fine discal bristles.

Legs light brown, front femora with one distinct strong black bristle caudal of the weaker apical bristles (Fig. 11). Wings brownish translucent without stigma.

Abdomen brown. Male genitalia (Figs 12, 13): Hypandrium and aedeagus without specific features. Gonocoxit of approximately rhombic shape with rounded edges. Gonostylus slightly bean - shaped, with some long black bristles in the lower part of its caudal margin. Its inner surface is covered by many short black spines situated mainly at its caudal part.

Size: Wing length: $2.8-3.1 \mathrm{~mm}\left(0^{7} 0^{\circ}\right), 3.0-3.2 \mathrm{~mm}$ (\&O). Body length: $2.5-3.3 \mathrm{~mm}\left(\sigma^{7} \sigma^{\prime)}\right), 2.9-3.0 \mathrm{~mm}$ (qO).

\section{Relations}

The coloration, body length, shape and chaetotaxy of the gonostylus distinguishes $W$. (Ch.) bravonae sp. $\mathrm{n}$. from its close relative $W$. (Ch.) corsicana Vaillant: $W$. (Ch.) corsicana is dark brown and distinctly taller as the brown to light brown W. (Ch.) bravonae. Its body length is $4.3-5.1 \mathrm{~mm}$ (Vaillant 1964), contrasted to the body length of $W$. (Ch.) bravonae of $2.5-3.3 \mathrm{~mm}$. The gonostylus of $W$. (Ch.) corsicana is much wider than the gonostylus of $W$. (Ch.) bravonae: the length to width ratio of the gonostylus of W. (Ch.) corsicana is about 1.3 , but about 1.8 in W. (Ch.) bravonae. W. (Ch.) bravonae has some long bristles on the lower caudal margin of the gonostylus which are absent in W. (Ch.) corsicana. The black spines of the inner surface of the gonostylus are located mainly caudally in $W$. (Ch.) bravonae but centrally in $W$. (Ch.) corsicana. Another difference is given by the existence of a wing stigma in $W$. (Ch.) corsicana which is lacking in W. (Ch.) bravonae.

\section{Etymology}

The species is named after the corsican river Riv. de Bravona.

Up to now W. (Ch.) bravonae sp. $\mathrm{n}$. has been found only at one place on Corsica in the $1 \mathrm{~m}$ wide Rau de Canale ( $900 \mathrm{~m}$ a.s.l.), a right tributary of Riv. de Bravona. This little stream is shaded by dense riparian vegetation; the stream bed is covered by calcareous encrustration. The new species occurred there together with $C$. (C.) nigra Meigen, $C$. (K.) cataractae sp. n., $W$. (R.) czernyi (Bezzi) and W. (W.) martini sp. n. Its close relative $W$. (Ch.) corsicana Vaillant has been collected at a left tributary of Riv. de Bravona at the opposite slope exposed to south.

\section{Wiedemannia (Chamaedipsia) corsicana Vaillant, 1964}

Material: 23. 7. 1992, station 2, $10^{\circ} ; 26.7 .1992$, station 6, 15 ơ 22 \%; 28. 7. 1992, station 12, 9 o' 6 \%; 28. 7. 1992, station 13, 4 o' 4 \%; 6. 6. 1993, station 41, 2 O' 2 \%; 7. 8. 1993, station 23, 3 ơ 1 \%; 7. 8. 1993, station 25, 25 o' 31 \&; 7. 8. 1993, station 26, 5 o' 6 \%; 7.8 . 1993, station 27,2 \% 7. 8. 1993, station $28,60^{\circ} 6$ \% 9 . 8. 1993, station 30, 12 o' 11 \%; 9. 8. 1993, station 31, 25 ơ 17 \%; 9. 8. 1993, station 32, 18 ơ 7 \%

W. (Ch.) corsicana Vaillant is an endemic species on Corsica (Vaillant 1978). It was collected frequently between 720 and $1700 \mathrm{~m}$ a.s.l. Vaillant (1964) found this species even as low as $15 \mathrm{~m}$ a.s.l. W. (Ch.) corsicana occurred in 1-6 $\mathrm{m}$ wide streams both in sunny and shady places.

\section{Wiedemannia (Philolutra) kallistes sp. n.}

Material: Holotype o', France, Corsica, second left tributary of Riv. Restonica above Bergeria Grotelle, Corte, at $1425 \mathrm{~m}$ a.s.1., $46^{\circ} 55^{\prime} \mathrm{N}, 7^{\circ} 26^{\prime} \mathrm{E}, 26.7$. 1992, paratypes 3 \% ibidem, $20^{7} 9$. 8. 1993, station 31 in coll. M. H. E. Pusch.

\section{Description}

Head rounded, dark brown with a pair of diverging ocellar bristles and 3-6 (mean 4.7) black postocular bristles in a single row, followed below by fine pale hairs which spread out to lower part of occiput. Palpi brown, bearing a few pale hairs.

Thorax brown to blackish brown, pronotum with one pair of stronger and two pairs of smaller bristles. Mesonotum with 13-19 (mean 15.7) pairs of acrostichals arranged behind in a single irregular row along each side of prescutellar depression, 5-7 pairs of dorsocentrals, 1 humeral, few minute posthumeral bristles, 1 presutural and some short fine bristles near them, 2 notopleural and some other short fine bristles near them, 1 postalar, scutellum with 2 long and 2-5 short terminal and some short fine discal bristles.

Legs dark brown, coxae with white hairs, front femora without a distinct stronger bristle (Fig. 14). Wings faintly brownish with an elongate stigma.

Abdomen dark brown. Male genitalia (Figs 15, 16): on the ventral side of the hypandrium four long bristles. Aedeagus without specific features. Gonocoxit approximately rectangular with rounded edges. Gonostylus triangular, its anterior margin with a notch. 

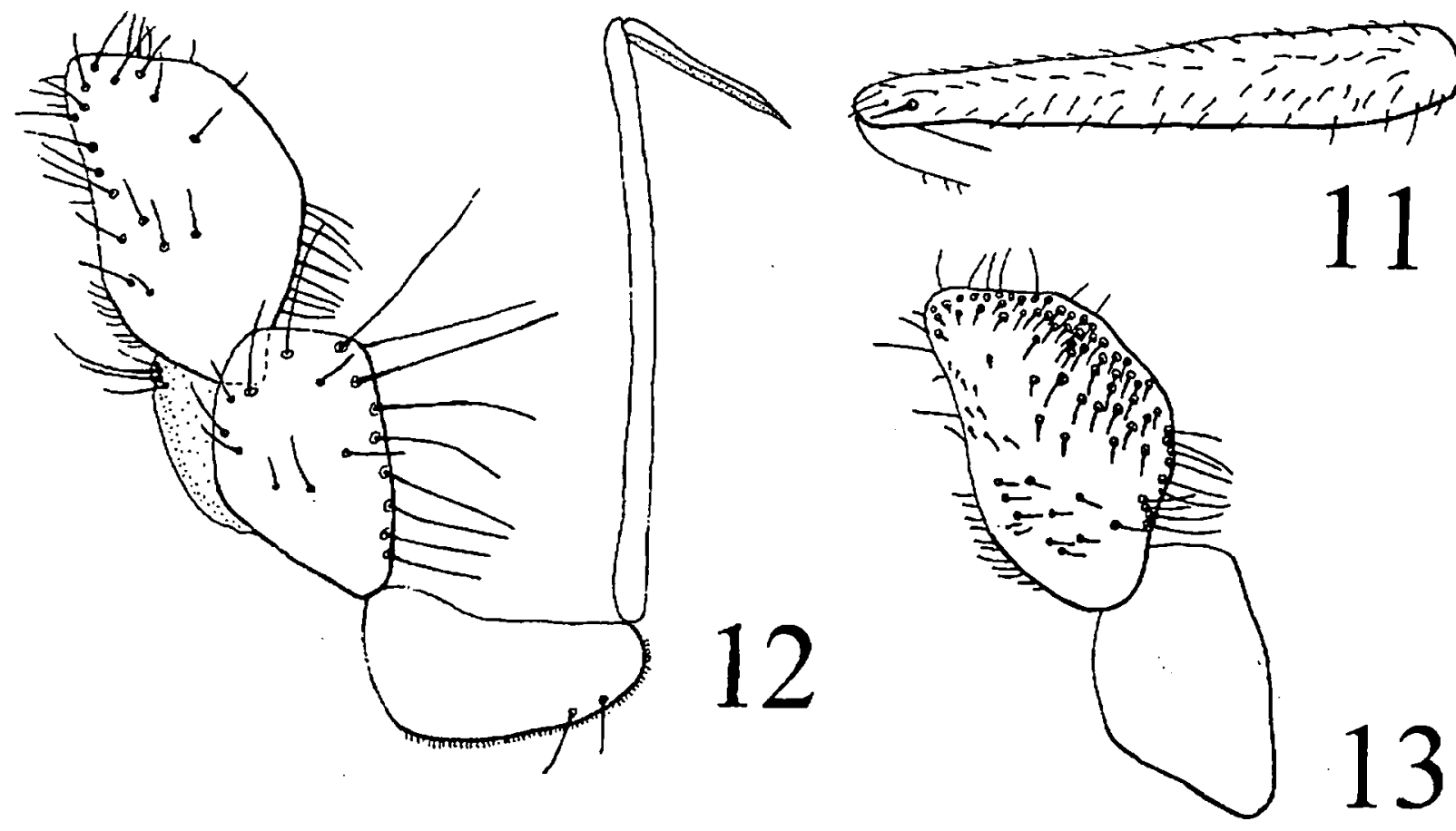

Figs 11-13. Wiedemannia (Chamaedipsia) bravonae. sp. n.. 11: inner view of right front leg, femur and proximal part of tibia. 12, 13: lateral view of male genitalia. 12: outer view, 13: inner view.

Figs 11-13. Wiedemannia (Chamaedipsia) bravonae n. sp.. 11 : vue interne de la patte antérieure droite, fémur et partie proximale du tibia. 12, 13 : vue latérale des genitalia ơ: vue externe (12), vue interne (13).

Its inner surface is covered by many short black spines below the notch, and longer black bristles near the caudal margin. Its ventral margin has a concave dent.

Size: Wing length: $4.0-4.8 \mathrm{~mm}\left(0^{7} 0^{7}\right), 4.5-5.0 \mathrm{~mm}$ (우). Body length: $3.8-4.8 \mathrm{~mm}\left(0^{7} 0^{7}\right), 3.5-4.0 \mathrm{~mm}$ (우).

\section{Relations}

Concerning the shape of the gonostylus the closest relatives of $W$. (P.) kallistes $\mathrm{sp}$. n. are W. (Ch.) ariadne Wagner from the Greek Cyclades islands Naxos and Andros, and $W$. (P.) bohemani Zetterstedt from the European continent. Yet the existence of a distinct stronger apical bristle on the front femora (Wagner 1981) distinguishes $W$. (Ch.) ariadne from the other two species which both belong to the subgenus Philolutra. The existence of only four longer bristles on the ventral side of the hypandrium is another difference between $W$. (P.) kallistes $\mathrm{sp} . \mathrm{n}$. and the related species W. (Ch.) ariadne and $W$. (P.) bohemani, which both have many bristles on the ventral side of the hypandrium. A further distinction is the shape of the gonostylus: the ventral margin of the gonostylus of $W$. (P.) kallistes is distinctly more concave than in $W$. (Ch.) ariadne, but less concave than in $W$. (P.) bohemani. The outline of the gonostylus of $W$. (P.) bohemani has a more rectangular shape, and not a triangular one like in $W$. (P.) kallistes and W. (Ch.) ariadne.

\section{Etymology}

The species is named after the old Greek name for Corsica, "Kalliste», which means «the most beautiful».

$W$. (P.) kallistes $\mathrm{sp}$. $\mathrm{n}$. has been found only at two places on Corsica: first in Rau de Tomba, a $6 \mathrm{~m}$ wide stream south of Ghisoni at $1400 \mathrm{~m}$ a.s.l., and second in a left little tributary of the Restonica, west of Corte at $1425 \mathrm{~m}$ a.s.l. Probably the new species is restricted to the higher mountains. It occurred in the Rau de Tomba together with $C$. (C.) nigra Meigen, $C$. $(K$.$) cataractae$ sp. n., C. (K.) tibiella Mik, W. (Ch.) corsicana Vaillant, and in the left tributary of the Restonica together with C. (C.) appendiculata (Zetterstedt), C. (C.) nigra (Meigen), $C$. (K.) tibiella Mik, $C$. (K.) schnabli (Becker) and W. (W.) martini sp. n..

\section{Wiedemannia (Roederella) czerny (Bezzi, 1905)}

Material: 23. 7. 1992, station 1, 34 o' 25 \%; 23. 7. 1992, station 2, $290^{\prime} 36$ \%; 23. 7. 1992, station 3, $610^{\prime \prime}$ 42 \&; 25. 7. 1992, station 4, 12 o' 19 \%; 25. 7. 1992, 


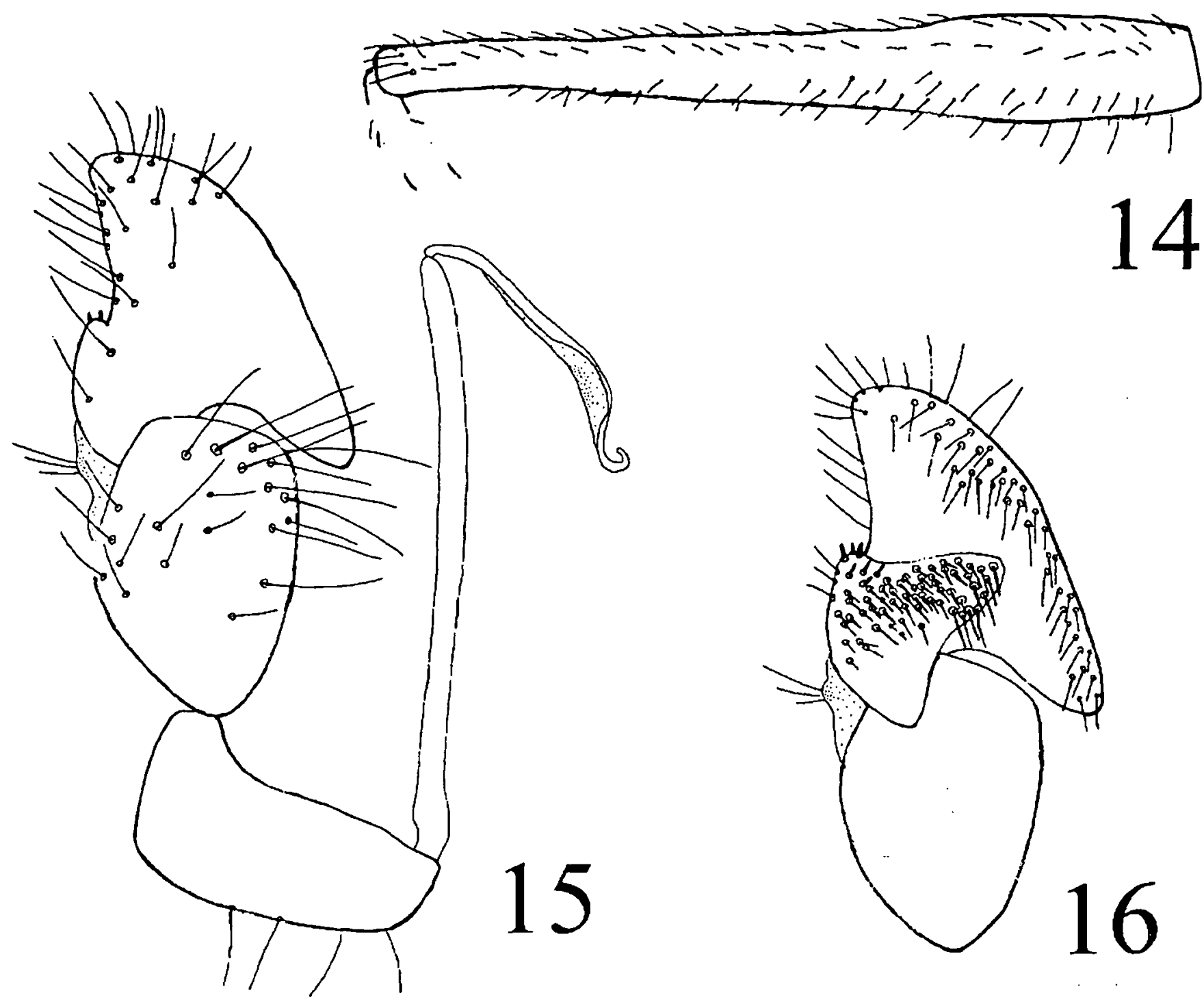

Figs 14-16. Wiedemainia (Philolutra) kallistes sp. n.. 14: inner view of right front leg, femur and proximal part of tibia. 15, 16: lateral view of male genitalia. 15: outer view, 16: inner view.

Figs 14-16. Wiedemannia (Philolutra) kallistes n. sp.. 14 : vue interne de la patte antérieure droite, fémur et partie proximale du tibia. 15, $16:$ vue latérale des genitalia $0^{\prime}$ : vue externe (15), vue interne (16).

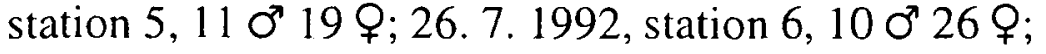
26. 7. 1992, station 9, $10^{\circ} 4$ \%; 27. 7. 1992, station 11, 6 ơ 6 \%; 28. 7. 1992, station 12, 2 ơ 17 \%; 28. 7. 1992, station 13, $60^{71} 10 \% ; 28.7$. 1992, station 14, $210^{71} 1 \%$; 28. 7. 1992, station 15, 3 o 6\%; 29. 7. 1992, station 17, $10^{7} 1$ \%; 29. 7. 1992, station $18,120^{\circ} ; 29.7$. 1992, station 20, 13 o' 7 \&; 3. 8. 1992, station 22, 9 o' 25 \&; 6. 6. 1993, station 41, 1 \%; 7.8. 1993, station 23, 63 o 44 \%; 7. 8. 1993, station 25, 14 ơ 22 \%; 7. 8. 1993, station 26, 10 o 9 \%; 7. 8. 1993, station 27, 9 o 13 \%; 7.8 . 1993, station 28, 11 o' 5 \%; 9. 8. 1993, station 30, 1 o'; 9. 8. 1993, station 33, 100 o 3 \%; 12.8. 1993, station 35, 5 o' 3 \%; 14. 8. 1993, station 37, 19 ơ 8 \%; 14. 8. 1993, station 38,10 .

W. (R.) czernyi (Bezzi) is distributed over Italy and Greece, too (Chvala \& Wagner 1989). On Corsica, it is the Clinocerinae species that is found most frequently. It was collected between 80 and $1700 \mathrm{~m}$ a.s.l., from 1 $\mathrm{m}$ wide streams to $8 \mathrm{~m}$ wide rivers, in sunny and shady places of rivers with low and high gradient. Occasionally $W$. (R.) czernyi was observed sucking a Heptageniidae subimago (Ephemeroptera) that had just emerged.

\section{Wiedemannia (Wiedemannia) martini sp. n.}

Material: Holotype ơ France, Corsica, Rau de Sambuchetto, near St Vincent below Mazolla, at $880 \mathrm{~m}$ a.s.1., $47^{\circ} 01^{\prime}$ N $, 7^{\circ} 47^{\prime} \mathrm{E}, 23.7$. 1992, paratypes ibid. $20^{\circ} 4$ \&; 23. 7. 1992, station 3, 2 \%; 26. 7. 1992, station 8, 3 ơ 4 \&; 29. 7. 1992, station 18, 1 o' 1 \&; 29. 7 . 
1992, station 19, 1 O'1 1 ; 7.8. 1993, station 28,4 0 6 \%; 9. 8. 1993, station 30, 3 ơ 3 \% in coll. M. H. E. Pusch.

\section{Description}

Head elongate, blackish brown, with a pair of diverging ocellar, a pair of vertical and 4-7 (mean 5.8) black stout postocular bristles in a single row, followed below by fine yellowish bristles. Antennae and palpi dark brown.

Thorax dark brown, pronotum with one pair of dark bristles and sometimes one smaller bristle nearby. Mesonotum with 5-10 (mean 8.3) pairs of acrostichals in front and 6-10 (mean 7.8) irregular pairs on each side of the prescutellar depression behind, 5-6 pairs of dorsocentrals, 1 humeral, 1-2 presutural and some short fi- ne bristles near them, 2-3 notopleural and some other short fine bristles near them, 1 postalar, scutellum with 2 long and 3-6 short terminal and some short fine discal bristles.

Legs dark brown, front femora with a single preapical bristle. Wings light brown with a distinct, rounded stigma well before the cubital fork.

Abdomen dark brown. Male genitalia (Figs 17, 18): hypandrium without specific features. Aedeagal filament somewhat longer than the half length of the aedeagus. Gonocoxit approximately quadrate with rounded edges. Gonostylus longer than wide, with two caudal extensions, the upper one rectangular the lower one roundish. The inner surface of the gonostylus with longer stoutish black bristles at the upper extension, and
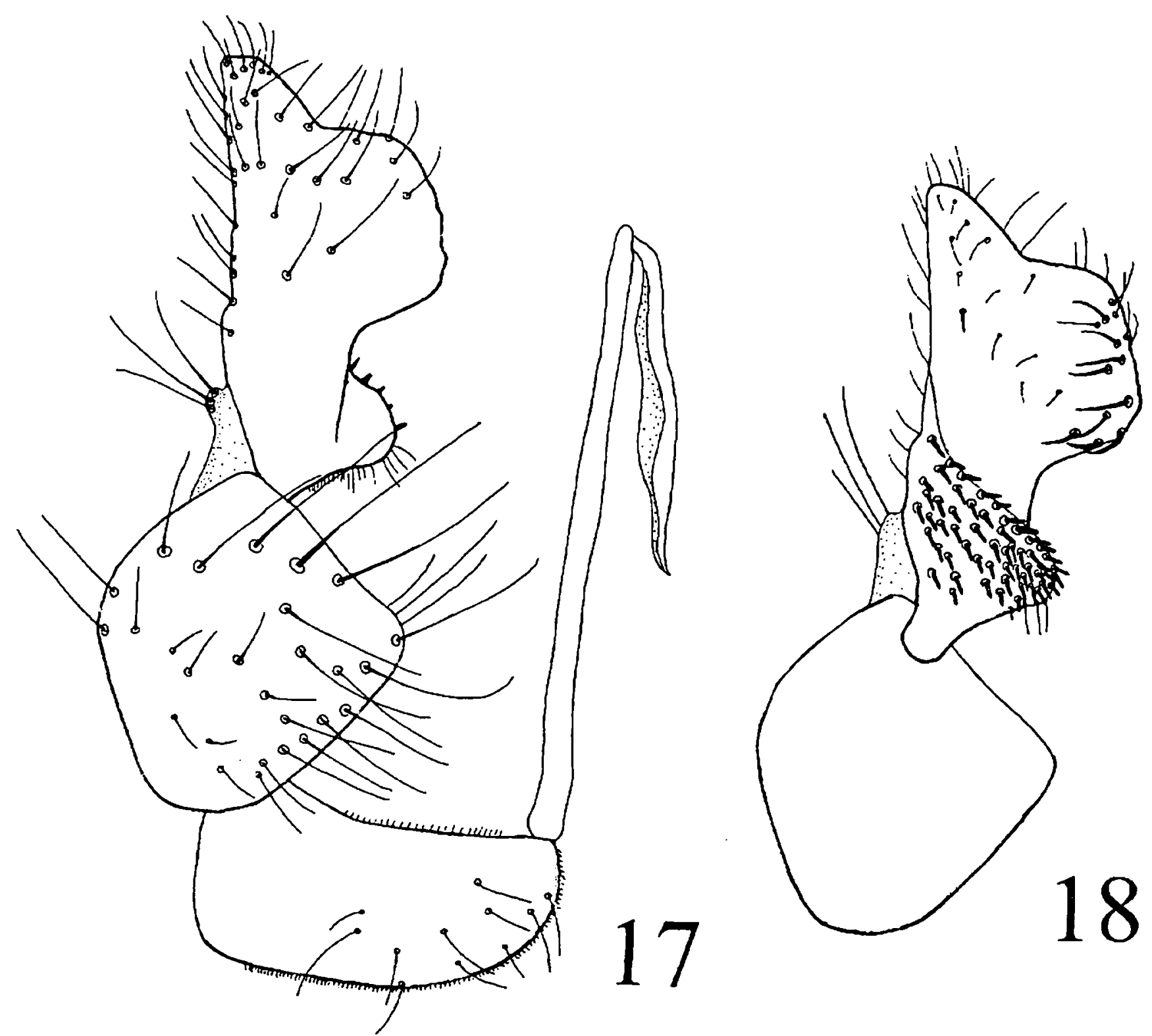

Figs 17-18. Lateral view of male genitalia of Wiedemannia (Wiedemannia) martini sp. n.. 17: outer view, 18: inner view. Figs 17-18. Vue latérale des genitalia ơ de Wiedemannia (Wiedemannia) martini n.sp. : vue externe (17), vue interne (18). 
short black spines at the whole surface of the lower extension.

Size: Wing length: $3.3-4.8$ (mean $4.1 \mathrm{~mm})\left(0^{7} \sigma^{7}\right)$, 3.7-5.0 mm (mean $4.4 \mathrm{~mm}$ ) (\%O). Body length: 3.2-4.5 $\mathrm{mm}$ (mean $4.0 \mathrm{~mm}$ ) $\left(\sigma^{7} \sigma^{7}\right), 3.5-4.8 \mathrm{~mm}$ (mean $4.3 \mathrm{~mm}$ ) (우).

\section{Relations}

The closest relatives of $W$. (W.) martini sp. n. are $W$. (W.) dinarica Engel from Bosnia, W. (W.) andreevi Joost from Bulgaria and Poland, and W. (W.) bistigma Curtis from the European continent. The gonostylus of $W$. (W.) dinarica has only one caudal extension and is therefore easily distinguished from the new species. The gonostylus of $W$. (W.) andreevi has two extensions, too, but the upper one is finger - shaped, and not rectangular like in W. (W.) martini. Additionally, the aedeagal filament of $W$. (W.) andreevi is shorter than the half length of the aedeagus. In the gonostylus of $W$. (W.) bistigma there is only the lower roundish extension, but it is not as marked as in W. (W.) martini. The upper rectangular extension is absent.

\section{Etymology}

The new species is dedicated to my husband, Dr. Martin Pusch for his enthusiastic help in sampling Clinocerinae.

W. (W.) martini sp. $\mathrm{n}$. has been found in seven localities on Corsica. It occurred between 880 and $1600 \mathrm{~m}$ a.s.l. at sunny and shady places in streams $1-6 \mathrm{~m}$ wide, both on projecting stones and in hygropetric zones. In the seven localities the new species was found five times together with $C$. (C.) nigra Meigen and $W$. (R.) czernyi (Bezzi) and four times with $C$. (K.) tibiella Mik. Moreover it occurred together with $R$. gereckei Wagner \& Horvat, $R$. wagneri sp. n., $C$. (C.) appendiculata (Zetterstedt), C. (K.) bipunctata (Haliday), $C$. (K.) cataractae sp. n., C. (K.) schnabli (Becker), W. (Ch.) ariolae sp. n., W. (Ch.) bravonae sp. n., W. (Ch.) corsicana Vaillant and $W$. (P.) kallistes sp. n..

\section{Discussion}

The number of taxonomic descriptions of new Clinocerinae species from the European continent in the last decade demonstrated that even there the Clinocerinae fauna is still far from being completely documented (e. g. Joost 1985, Vaillant \& Vinçon 1986, Niesiolowski 1987, Horvat 1993, Pusch \& Wagner 1993, Wagner 1995). The Mediterranean region, including its islands, is still less investigated in this respect. Up to now seven species of Clinocerinae have been known from Corsica, including two endemic ones (Vaillant 1964, Wagner 1995). If the results of the two collection tours reported here are added, the number rises to 17 known species. However, there are presumably unknown species present yet.

The six new species described here probably all are endemic to Corsica. Their closest relatives have been found on the European continent. During the pleistocene glaciations, the considerable drop of the water level of the Mediterranean caused a short phase of terrestric contact between the Italian Toscana region and the island of Corsica (La Greca 1990). It can be supposed that at that time the Clinocerinae fauna from the continent and the island exchanged. After the sea level had rosen again, geographic isolation, together with differing environmental conditions, lead to a genetic and morphological separation of the Corsican populations of some Clinocerinae species. The evolution of these Corsican species can be seen as a case of neoendemism (Banarescu \& Boscaiu 1978) or schizoendemism sensu Giudicelli (1975).

\section{Acknowledgements}

I am thankful to Prof. Dr. R. Wagner, Schlitz, who showed me some type specimens from his collection, and for reading the manuscript. I also thank Dr. H. Schumann, Naturkundemuseum Berlin, and Mr. J. Ziegler. Deutsches Entomologisches Institut at Eberswalde, Germany, who enabled the examination of some type specimens of Clinocerinae. Further I want to thank Dr. R. Gerecke, Tübingen for the donation of some specimens collected on Corsica.

\section{References}

Banarescu P. \& Boscaiu N. 1978. - Biogeographie, VEB G. Fischer Vlg. Jena.

Becker T., Kuntze, A., Schnabl, J. \& Villeneuve, E. 1910. Dipterologische Sammelreise nach Korsika. (Dipt.) Deutsche Ent. Zeitschr., 6: 635-665.

Chvala M. \& Wagner R. 1989. - Empididae. In Soos A., Papp L. (eds.): Catalogue of Palaearctic Diptera, Vol. 6, Elsevier Sci. Publ., Amsterdam, Akademiai Kiado, Budapest: 312-335.

Giudicelli J. 1975. - Analyse de l'endémisme dans la faune des eaux courantes de la Corse. Ecologia Mediterranea, 1: 133-147.

Horvat B. 1993. - Bergenstammia carnioloca sp. n. (Diptera, Empididae: Clinocerinae) from Karavanke Mts. in Slovenia. Acta Univ. Carolinae - Biologica, 37: 73-76.

Illies J. 1966. - Die Verbreitung der Süßwasserfauna Europas. Verh. Internat. Ver. Limnol. 16: 287-296.

Joost W. 1985. - Dolichocephala bellstedti $\mathrm{n}$. sp. aus Th, ringen (DDR) (Diptera, Empididae). Ent. Nachr. und Ber., 29: 277 278.

La Greca M. 1990. - The insect biogeography of West Mediterranean Islands. Atti Conv. Linc., 85: 469-491.

Niesiolowski S. 1987. - Wiedemannia jazdzewskii sp. n. and Hemerodromia mazoviensis sp. n., new species of Empididae (Diptera, Brachycera) from Poland. Pol. Pis. Ent., 57: 519-522.

Pusch M.H.E. \& Wagner R. 1993, - Bergenstammia aurinae sp. n., a new aquatic Empidid (Diptera) from the Eastern Alps. Aquatic Insects, 15: 209-212.

Vaillant F. 1964. - Revision des Empididae Hemerodromiinae de France, d'Espagne et d'Afrique du Nord (Dipt.). Ann. Soc. Ent. Fr., 133: 143-171.

Vaillant F. 1978. - Empididae. In Illies J. ed.: Limnofauna Europea. 2 ed. Gustav Fischer Verlag \& Swets \& Zeitlinger Stuttgart: $465-469$. 
Vaillant F. \& Vinçon G. 1986. - Quelques Clinocerini (Diptera, Empididae, Hemerodromiinae) nouveaux ou mal connus des Pyrénées. Annls Limnol., 22: 261-275.

Wagner R. 1981. - Über einige Hemerodromiinae vom Balkan und aus der Ägäis. Spixiana, 4: 297-304.
Wagner R. 1995. - Empididen aus dem Mittelmeerraum (Diptera, Empididae: Hemerodromiinae and Clinocerinae). Acta Ent. Slovenica, 3: 5-23.

Wagner R. \& Horvat, B. 1993: - The genus Roederiodes Coquillett, 1901 Diptera, Empididae: Clinocerinae in Europe, with descriptions of four new species. Bonn. zool. Beitr., 44: 3340 . 